\title{
Insights into hazardous solid waste generation during COVID-19 pandemic and sustainable management approaches for developing countries
}

\author{
Bashir Adelodun ${ }^{1,2}$ (1) Fidelis Odedishemi Ajibade $^{3,4,5} \cdot$ Rahmat Gbemisola Ibrahim $^{6} \cdot$ Joshua O. Ighalo $^{7,8}$. \\ Hashim Olalekan Bakare ${ }^{7}$ Pankaj Kumar ${ }^{9} \cdot$ Ebrahem M. Eid $^{10,11} \cdot$ Vinod Kumar $^{9} \cdot$ Golden Odey $^{1}$. \\ Kyung-Sook Choi ${ }^{1,12}$ (D)
}

Received: 15 January 2021 / Accepted: 30 July 2021 / Published online: 6 August 2021

(c) Springer Japan KK, part of Springer Nature 2021

\begin{abstract}
The recent emergence of the COVID-19 pandemic has contributed to the drastic production and use of healthcare and personal protective equipment, leading to the release of a huge quantity of hazardous medical and solid wastes in the environment. Meanwhile, these solid wastes may contribute to the spread of the SARS-CoV-2 viral particles when disposed of without proper treatment and care. Since SARS-CoV-2 could persist on different material surfaces including plastic, steel, paper, cardboard, cloth, and wood, proper management of these hazardous solid wastes has become a challenging task during the COVID-19 pandemic. In this paper, an overview of the consumption of COVID-19-related healthcare and personal protective equipment along with the production of hazardous solid waste is presented. The efficient management of these wastes is necessary to prevent the entering of SARS-CoV-2 in various environmental compartments. Therefore, some preventive measures including the use of biodegradable materials for manufacturing personal protective equipment, minimizing the use of non-biodegradable materials, efficient pre- and-post planning, careful segregation, and disposal are, therefore, proposed for their sustainable management. The findings reported in this paper contribute to tackling the problems associated with hazardous solid waste management, particularly for low- and middle-income countries.
\end{abstract}

Keywords Coronavirus $\cdot$ COVID-19 $\cdot$ Household waste $\cdot$ Medical waste $\cdot$ SARS-CoV-2 $\cdot$ Waste management

Bashir Adelodun

adelodun.b@unilorin.edu.ng

$\triangle$ Kyung-Sook Choi

ks.choi@knu.ac.kr

1 Department of Agricultural Civil Engineering, Kyungpook National University, Daegu, Korea

2 Department of Agricultural and Biosystems Engineering, University of Ilorin, PMB 1515, Ilorin, Nigeria

3 Department of Civil and Environmental Engineering, Federal University of Technology, PMB 704, Akure, Nigeria

4 Key Laboratory for Environmental Biotechnology, Research Centre for Eco-Environmental Sciences, Chinese Academy of Sciences, Beijing 100085, China

5 University of Chinese Academy of Sciences, Beijing 100049, People's Republic of China

6 Kwara State Ministry of Health, Ilorin, Kwara, Nigeria
7 Department of Chemical Engineering, Faculty of Engineering and Technology, University of Ilorin, PMB 1515, Ilorin, Nigeria

8 Department of Chemical Engineering, Nnamdi Azikiwe University, PMB. 5025, Awka, Nigeria

9 Agro-Ecology and Pollution Research Laboratory, Department of Zoology and Environmental Science, Gurukula Kangri (Deemed To Be University), Haridwar 249404, Uttarakhand, India

10 Biology Department, College of Science, King Khalid University, Abha 61321, Saudi Arabia

11 Botany Department, Faculty of Science, Kafrelsheikh University, Kafr El-Sheikh 33516, Egypt

12 Institute of Agricultural Science and Technology, Kyungpook, National University, Daegu, Korea 


\section{Introduction}

Solid waste management is one of the long-time contending issues around the world, with the aggravated situation in cities of the developing countries. The current pandemic of COVID-19, which started in late December 2019 and subsequently declared as a global public health crisis on January 30, 2020, by the World Health Organization [1], spreading to 213 countries with more than 20 million confirmed infected people and about 7,44,000 deaths as of 13 August 2020, majority of which are due to community transmission [2], is creating further challenges on the waste management industry. The increasing solid waste and wastewater generations, their improper treatments arising from a growing population, and human interactions and activities in developing countries [3] could serve as potential drivers for the spread of COVID-19 and its devastating impact on the environment $[4,5]$. While sustainable approaches to preventing COVID-19 spread through wastewater have received significant attention [6-8], the management of solid waste as related to COVID-19 is limited [5, 9]. Also, the production of personal protective equipment (PPE) kits, including hand gloves, facemasks, white gowns, and rubber boots, and other essential medical items such as specimen bottles and syringes, among many others, have increased considerably, leading to a significant amount being discarded in the environment after use [9-11]. Furthermore, a serious concern of sustainable management of immense solid wastes that are being generated in the course of tackling the COVID-19 pandemic has been raised $[12,13]$.

Among the urgent measures recommended by the WHO to mitigate the further spread of the COVID-19 is the use of personal protective equipment (PPEs) by the healthcare personnel and other people tending to the infected COVID-19 patients, and also the use of facemasks by the individual in public places. On this note, many countries have mandated the use of facemasks in a public gathering with a serious fine, including jail term for any individual flouting the rule [14]. This measure has created an upsurge in the production and use of facemasks in many countries, while the management of the solid waste generated specifically from the use of PPEs, including facemask, is often not in place. Table 1 indicates the estimated daily number of facemasks usage in some selected developing countries following the method reported by [15].

The percentage increase of COVID-19 confirmed cases above $1000 \%$ in the majority of the developing countries since May 1, 2021, indicating a possible rise in the number of facemasks (estimated daily facemasks above 10 million for many of the countries) when the majority of these countries implemented the facemasks measure for all the residents (Table 1). While serious attention is given to the used PPEs by the health personnel on their handling, disinfection, and disposal, the facemask, which is the most common type of PPEs, is often disposed of indiscriminately in the environment [12]. Moreover, a case of improper handling of used health-care personnel-based PPE was reported in Nigeria [15], one of the developing countries with the most population in Africa. There are no existing concrete measures in place for the collection, disinfection, and disposal of used facemasks and other PPEs in many developing countries during this COVID-19 pandemic, especially those generated from the household level [17]. Zand and Heir [10] reported the increase in the landfilling of solid wastes, including the hospital wastes, as a means of solid waste management during the ongoing COVID-19 pandemic, which could lead to contamination of environmental compartments such as soil and groundwater $[18,19]$. The ease of nationwide lockdown measures in many of these countries has led to the littering of disposable gloves and facemasks [13,20], which are expected to aggravate the situation on community-based waste management. Moreover, most of the chemically synthesized materials that are being used for the production of facemasks and other PPEs are non-biodegradable polymers and could remain in the environment for many years if they are improperly disposed of. This paper, therefore, provides an overview of solid waste management in recent years in developing countries and discusses the readjustment of the management strategies in light of the current COVID-19 pandemic. Furthermore, some policy frameworks and possible sustainable measures that could be adopted for the developing nations to forestall the spread of the COVID19 via household and medical wastes were proposed.

\section{Challenges of solid waste management in the developing countries during the COVID-19 pandemic}

The increasing solid waste generation in some of the developing countries has always been a source of environmental concern, especially in the cities where the population tends to be extremely high due to increased rural-urban migration. The advent of the COVID-19 pandemic has further turned the situation into a quagmire with heightened health risks. The proliferation of improperly disposed and contaminated PPEs is the new challenge to be faced in the waste management sector, posing greater environmental and health issues $[10,20]$. For instance, about $3.4 \mathrm{~kg}$ of hazardous wastes is expected to be generated daily by each infected person in Bangladesh who are being isolated and quarantined in their various homes due to limited capacity in the healthcare facilities [17], while China and some other developing 
Table 1 Estimated daily facemasks usage in some selected developing countries with the COVID-19 increase rate

\begin{tabular}{|c|c|c|c|c|c|}
\hline Country & $\begin{array}{l}{ }^{\text {aPopulation }} \\
\text { (million) }\end{array}$ & $\begin{array}{l}{ }^{\mathrm{a} C O V I D-19} \text { cases } \\
\text { (May } 1,2020)\end{array}$ & $\begin{array}{l}{ }^{\mathrm{a}} \text { COVID-19 cases (Janu- } \\
\text { ary } 10,2021)\end{array}$ & $\begin{array}{l}\text { Percentage increase of } \\
\text { confirmed cases }(\%)\end{array}$ & $\begin{array}{l}{ }^{\mathrm{b}} \text { Estimated daily face- } \\
\text { masks usage (million) }\end{array}$ \\
\hline Brazil & 212.56 & 92,109 & $80,75,998$ & 8668 & 299.28 \\
\hline India & 1380.00 & 37,257 & $1,04,51,346$ & 27,952 & 772.80 \\
\hline Iran & 83.99 & 95,646 & $12,80,438$ & 1239 & 102.14 \\
\hline Pakistan & 220.89 & 18,092 & $1,76,617$ & 2677 & 123.70 \\
\hline Bangladesh & 164.69 & 8238 & $1,12,306$ & 6229 & 102.77 \\
\hline South Africa & 59.31 & 5951 & 92,681 & 20,303 & 63.58 \\
\hline Columbia & 50.88 & 7006 & 65,633 & 25,184 & 0.65 \\
\hline Egypt & 102.33 & 5895 & 53,758 & 2424 & 70.41 \\
\hline Indonesia & 273.52 & 10,551 & 45,891 & 7656 & 245.08 \\
\hline Argentina & 45.20 & 4532 & 41,204 & 37,729 & 0.67 \\
\hline Philippines & 109.58 & 8772 & 30,052 & 5438 & 82.40 \\
\hline Oman & 5.11 & 2447 & 29,471 & 5215 & 7.11 \\
\hline Iraq & 40.22 & 2153 & 29,222 & 27,876 & 46.98 \\
\hline Afghanistan & 38.81 & 2335 & 28,833 & 2191 & 15.53 \\
\hline Bolivia & 11.67 & 1167 & 23,512 & 14,707 & 0.13 \\
\hline Nigeria & 206.14 & 2170 & 19,808 & 4465 & 171.51 \\
\hline Ghana & 31.07 & 2074 & 13,717 & 2589 & 28.34 \\
\hline Algeria & 43.85 & 4154 & 11,631 & 2353 & 51.22 \\
\hline Cameroon & 26.55 & 1832 & 11,610 & 1366 & 23.79 \\
\hline Morocco & 36.91 & 4569 & 9957 & 9785 & 37.80 \\
\hline Sudan & 43.85 & 442 & 8580 & 5175 & 24.56 \\
\hline Ivory Coast & 26.38 & 1333 & 7276 & 1662 & 21.52 \\
\hline Uzbekistan & 33.47 & 2086 & 6272 & 3619 & 26.78 \\
\hline Senegal & 16.74 & 1024 & 5888 & 1951 & 13.13 \\
\hline DR Congo & 89.56 & 604 & 5826 & 3072 & 65.92 \\
\hline Ethiopia & 114.96 & 133 & 4532 & 95,984 & 38.63 \\
\hline Kenya & 53.77 & 411 & 4478 & 23,789 & 24.09 \\
\hline Sri Lanka & 21.41 & 690 & 1950 & 6833 & 6.17 \\
\hline Paraguay & 7.13 & 266 & 1362 & 43,143 & 0.07 \\
\hline Yemen & 29.83 & 7 & 922 & 29,957 & 18.13 \\
\hline
\end{tabular}

${ }^{\text {a }}$ Source: Worldometer [16]

${ }^{\mathrm{b}}$ Calculation method was adapted from Nzediegwu and Chang [15]

countries are expected to generate more of the hazardous wastes [21,22]. While there is an existence of green and sustainable measures for solid waste management in the developed countries to sustain and manage the increasing use and after use of PPEs [15], the existing waste management structure in the developing nations is inadequate and lack the capacity to sustainably manage the rising and hazardous nature of emergent SARS-CoV-2-contaminated solid waste.

Among the several challenges solid waste management is facing in developing countries, the environmental behavior, attitude, and perception of the residents toward waste management, especially at household and community-based levels, are some of the profound factors responsible for poor waste management [22]. For instance, a funeral attendee of a deceased from COVID-19 complication openly disposed of the worn PPEs immediately after attending the burial in Nigeria [23], which could have been easily scavenged for reuse unknowingly without proper decontamination. The lack of attitude to community participation in solid waste management due to the non-existence of synergy among the various actors involved in waste management was identified in Zimbabwe [24]. Similarly, despite understanding the challenges involved in waste management, the residents of a community in South Africa reported to have not involved in a community participation to address the menace pose by the generated wastes within their community [25]. The residents and households of some of the developing countries often perceive that it is the sole responsibility of the government or the municipality to handle solid waste management [9, 24]. However, due to the complexity of waste management 
and the rising population with emerging hazardous wastes generated from the pandemic, there is a need for holistic approaches involving various stakeholders, including households, communities, waste managers, and policymakers.

One of the efficient ways identified to sustainably manage solid waste is source separation [26]. However, the inability to implement source separation of solid waste materials into different categories at household levels in many developing countries creates barriers to achieving sustainable waste management [27]. Oyedotun et al. [9] found that a significant percentage of sampled households from Nigeria (57.5\%) and Guyana (63.4\%) confirmed the presence of PPEs, with potential contamination, in their general household solid waste. The knowledge gap regarding environmental problems was responsible for poor and unsustainable waste management in the developing and low-income countries [22, 25]. Inadequate concern due to a considerable low level of awareness of waste contamination by the SARS-CoV-2 has been demonstrated in some developing countries, resulting in a lack of knowledge on the treatment of such contaminated wastes and improper waste management $[5,9,28]$. The open dumping of solid waste and poorly managed landfills are the common practice of waste management in developing and less developed countries, where scavengers and waste pickers freely access and retrieve potentially contaminated materials for sales and reuse $[15,18]$.

Solid waste management is capital intensive, with the government often responsible for the financial burden [29]. This approach is deemed not sustainable, as the government is often unable to live up to the expectation of the financial responsibility of waste management [25]. Meanwhile, the willingness to pay for the improved waste management in some of the developing countries is largely based on the level of environmental awareness, education level, and monthly income of the residents and households [26, 30, 31]. However, indiscriminate solid waste disposals, including open dumping, unregulated disposal, and open burning, are being practiced, especially when the stringent rule to preventing such are not in place [22]. There are cases where waste management personnel often embark on industrial strikes due to non-payment of their wages, thereby resulting in an alteration in waste collection schedules for a long time [22, 32]. The irregular frequency of waste collection service was identified as one of the reasons for poor waste management in Syria, while some residential areas have no waste collection service, leaving the residents to engage in indiscriminate disposals of their wastes [22].

Safe and suitable waste management is very critical during this pandemic to tackle the COVID-19 menace, which has put the whole world at risk. The generated wastes from this epidemic, irrespective of the source, should be treated as hazardous or infectious and be separately disposed of to ensure minimal impacts on public health (human health and the environment) $[33,34]$. This is consequent upon the fact that there is a high possibility of contamination of substances in the domestic and non-healthcare environment since the use of face masks, hand gloves, and other PPEs has become a general practice or norm in the public space and not only in the health sector. In a broader perspective, the haphazardly managed waste can adulterate the oceans, clog drains and cause flooding, transmitting diseases through the breeding of vectors, snowballing respirational issues via airborne particles from waste burning, hurting animals that unknowingly feed on waste, and adversely affect the economic development. To this end, there is the need for urgent action at all levels of society through planning sustainable, healthy, and green approaches for the management of solid wastes such as expended PPEs to curtail the proliferation of COVID-19.

The persistence of SAR-CoV-2, a virus causing COVID19 on the material surfaces, including plastic and stainless steel up to $72 \mathrm{~h}$ was previously reported [35]. The droplets on the facemask could contain some viral RNA of SARCoV-2, especially from asymptomatic individuals which might be handled carelessly by waste managers or found their way into the environment without proper decontamination. Meanwhile, the majority of the facemasks are often made of or contain polypropylene, which is a form of plastic material. This material is difficult to degrade naturally in the environment and could be another potential of pollution to the aquatic environment [36]. Figure 1 provides an overview of potential sustainable measures for household and medical wastes associated with COVID-19 spread in the environment.

\section{Management and mitigation strategies for solid wastes associated with COVID-19}

In this section, the most recent mitigation strategies for the management of medical wastes are discussed. Special focus is placed on papers on the subject published in the last 5 years and the goal is to evaluate how these mitigation strategies could be influenced in light of the COVID-19 pandemic. The need to study HSW disposal especially in scenarios where there are isolated patients with infectious diseases was raised [37]. Though most studies have evaluated these techniques from an environmental perspective, the effectiveness of these techniques for dealing with such waste to prevent the spread of the COVID-19 virus was deliberated in the section.

Hospital solid waste includes chemical waste, radioactive waste, tissue wastes, pharmaceutical and cytotoxic waste, and mixed waste [38, 39]. Negligence of HSW in itself can be quite risky [40]. The peculiarity of hospital solid waste is that it can contain infectious diseases [41], 


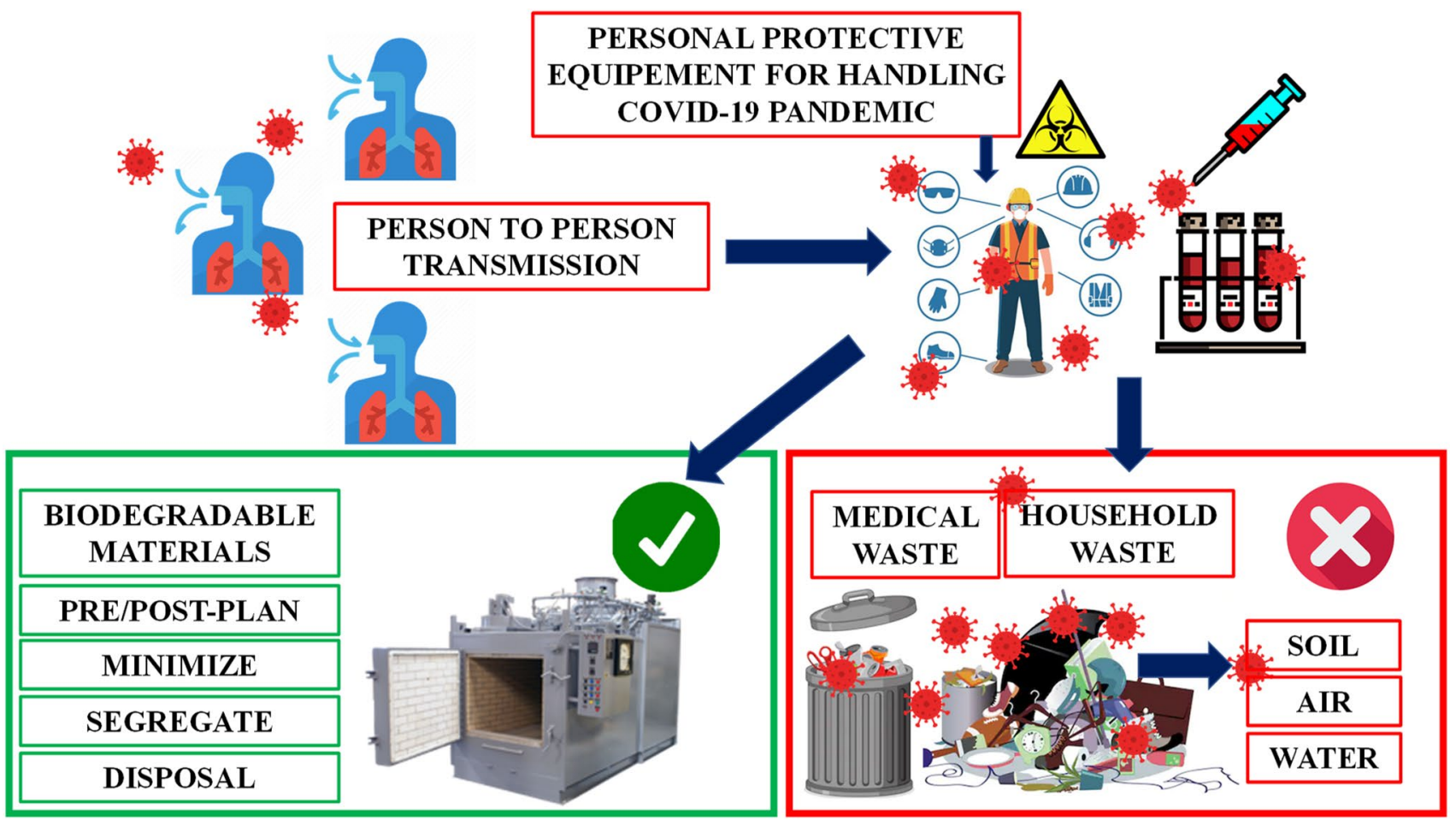

Fig. 1 Solid waste associated with COVID-19 spread with potential sustainable measures

of which COVID-19 is not an exception. About $15 \%$ of the waste generated by hospitals is considered to be hazardous [42]. Open dumping and landfilling are generally not advisable techniques for disposing of HSW as it leaves the waste vulnerable to human exposure $[18,43]$. However, these approaches of solid waste disposals are often found in developing countries [44], with indiscriminate dumping, landfilling, and open dumping/burning accounted for 65, 25, and $10 \%$, respectively, of solid waste disposal methods in Liberia [45]. The management techniques for solid waste should involve segregation, collection/on-site transportation, on-site storage, and off-site transportation [46, 47]. In some larger facilities/hospitals, the waste management system can be on-site. Segregation is a key aspect of waste management that has to be done carefully and with appropriate PPE to avoid infection [46].

Some of the countries in the developing nation lack a proper policy framework to address the enormous solid waste generation rates [45]. For instance, in Ogbomoso town, Nigeria, it was observed that there was no government-assisted infrastructure for the recovery, disposal, and/ or recycling of hospital waste [48]. Though this in itself is risky, incineration, and burning as a disposal technique would be effective for COVID-19-infected waste due to the high temperature involved. It has been established that techniques such as pyrolysis and chemical disinfection are more effective in dealing with hospital solid waste (HSW) than incineration and landfilling from an environmental perspective, albeit considering Swat district, Pakistan [49]. For COVID-19, chemical disinfection would be effective for the virus and pyrolysis would also give positive results due to the high temperature used. These scenarios bode well for HSW management. Similar conclusions on the poor environmental impact of incineration and landfilling as against composting arrived at for the case of Gujranwala, Pakistan [50]. For COVID-19, composting would likely not lead to the spread of the virus if the system is done on a separate vessel and appropriate safety precautions are taken in waste handling.

Other techniques for handling HSW include autoclaving (steam sterilization) and microwaving [51, 52] and these are virus effective too. More novel technologies that can be implemented include low-temperature plasma, irradiation technology, reverse polymerization, and bio-converters [52]. For cases where there is a lack of an integrated system for the management of solid waste, the possible spread of the pandemic would invariably become a serious issue. Lack of management system for HSW has been reported in hospitals in places like Aligarh, India [53], Lagos, Nigeria [46], Hormozgan province, Iran [54], Patiala city, India [55], Rajshahi City, Bangladesh [56], Pokhara, Nepal [57] and Anambra, Nigeria [58].

A summary of the legislation for hospital waste handling and disposal for different developing countries is presented 
by [38]. These would need to be reviewed and revised in light of the current global health challenges and the need for more caution in waste handling. From the future perspective, the integrated recycling, waste reduction, and reuse, and solar energy applications for utilizing HSW were proposed [59]. In the current scenario of COVID-19, the applicability and safety of such techniques will come under more scrutiny. A more detailed presentation of the key research recent findings on hospital solid waste (HSW) management in the last 5 years is given in Table 2 .

\section{Policy response and implications of solid waste management in the face of pandemics}

The waste management policies that are currently practiced at various levels of developing countries are found to be ineffective, inefficient, and unsustainable, as the formulation and implementations of such policies are carried out at different levels of government independently [9], thereby creating a synergistic gap. Although the current COVID-19 pandemic was never envisaged, the existing inadequate structure and inefficiencies in the waste management in many of the developing countries need appropriate policy rejigging and adequate policymakers interventions in terms of sustainable approaches to mitigate the potential cross-contamination through the improper disposal of used PPEs and imminent post-COVID 19 littering epidemics. The following sustainable approaches are proposed to competently manage solid wastes especially used PPEs, including facemasks, during and after the COVID-19 contagion:

Firstly, there is a need for sensitization on communitywide participation in waste management. The era of leaving the waste management solely for the government is unsustainable due to increasing population, waste generation rates, and an unexpected scenario like the current COVID-19 pandemic. The management of different kinds of waste at both individual households and community levels should be

Table 2 Recent research findings on hospital solid waste (HSW) management

\begin{tabular}{|c|c|c|}
\hline Location & Key findings & Reference \\
\hline Ogbomoso, Nigeria & $\begin{array}{l}\text { The government did not assist in the waste disposal and there was no recycling of waste. Disposal } \\
\text { was majorly by incineration/burning and landfill }\end{array}$ & [48] \\
\hline Swath district, Pakistan & $\begin{array}{l}\text { Pyrolysis or chemical disinfection was more effective in dealing with HSW than incineration and } \\
\text { landfilling }\end{array}$ & [49] \\
\hline Aligarh, India & Most hospitals in the region did not have an HSW management system & {$[53]$} \\
\hline Gujranwala, Pakistan & $\begin{array}{l}\text { Landfill and incineration were less effective than incineration for dealing with HSW from an envi- } \\
\text { ronmental perspective }\end{array}$ & {$[50]$} \\
\hline Nablus, Palestine & $\begin{array}{l}\text { System dynamics modeling was used to develop a comprehensive and sophisticated prediction of } \\
\text { hospital waste generation }\end{array}$ & {$[60]$} \\
\hline Developing countries & $\begin{array}{l}\text { Most developing countries have a high level of hazardous waste in their HSW beyond the WHO } \\
\text { standards }\end{array}$ & {$[61]$} \\
\hline Sant'Ana do Livramento, Brazil & $\begin{array}{l}\text { Most of the health professionals at the hospital were aware of the risks of the wastes and handled } \\
\text { them carefully for disposal }\end{array}$ & {$[62]$} \\
\hline Lagos, Nigeria & $\begin{array}{l}\text { In most hospitals in the area, there were no internal policies or guidelines in place for managing the } \\
\text { wastes }\end{array}$ & [46] \\
\hline Hormozgan province, Iran & About $9.45 \%$ of the waste generated is hazardous and there are still serious disposal issues & {$[54]$} \\
\hline Tehran, Iran & $\begin{array}{l}\text { In most hospitals, the waste was properly segregated and disinfected and only a few hospitals } \\
(20 \%) \text { had HSW storage }\end{array}$ & {$[63]$} \\
\hline Patiala city, Punjab, India & $\begin{array}{l}\text { There was an absence of proper waste management and a general lack of awareness of the hazards } \\
\text { of HSW }\end{array}$ & {$[55]$} \\
\hline Rajshahi City, Bangladesh & $\begin{array}{l}\text { The unsafe practice of open dumping was still practiced and clinical waste was not separated from } \\
\text { non-hospital waste }\end{array}$ & {$[56]$} \\
\hline Pokhara, Nepal & $\begin{array}{l}\text { Hazardous wastes in the HSW were above WHO limits and awareness of safe disposal techniques } \\
\text { was low }\end{array}$ & {$[57]$} \\
\hline Jogyakarta, Indonesia & The waste was properly handled but recycling has not been considered & {$[64]$} \\
\hline Mazandaran province, Iran & $\begin{array}{l}36.1 \% \text { of the HSW generated was hazardous and over half the hospitals considered disposal of their } \\
\text { waste by incineration }\end{array}$ & {$[65]$} \\
\hline Anambra, Nigeria & $\begin{array}{l}\text { The key issue in the disposal chain was the unavailability of suitable materials for waste segrega- } \\
\text { tion }\end{array}$ & {$[58]$} \\
\hline Ile-Ife, Nigeria & $\begin{array}{l}\text { The methods used and materials employed in storage and disposal was not in agreement with } \\
\text { WHO standards }\end{array}$ & {$[66]$} \\
\hline Shimla City, India & HSW generation was properly handled and the practitioners were aware of its risk & [47] \\
\hline
\end{tabular}


encouraged. For instance, during the peak of the COVID-19 pandemic and the implementation of lockdowns, some countries suspended waste management and recycling activities due to the fear of contracting the COVID-19 through contaminated materials [17]. This singular act resulted in overflowing of waste bins with different kinds of waste including organic wastes and plastics, and littering of the street with household waste materials $[67,68]$, leading to foul smells in many streets due to lack of appropriate knowledge on waste management at the household level and non-existence of community waste management participation $[17,22]$. The gap of inadequate manpower in the waste management sector can be filled by integrating the scavengers and waste pickers properly into the fold of the waste management sector at the community level by providing them with the necessary training, and essential protection equipment and kits to safeguard them from any injury and infections associated with the work.

Secondly, the incorporation of source separation into the popular 3Rs (reduce, reuse, and recycle) of sustainable waste management is an essential way to prevent the cross-contamination of infections from the likes of COVID-19 pandemic, while pursuing the United Nations sustainable development goal (SDGs) of sustainable cities and communities. Source separation would ensure the removal of the hazardous wastes right from the source while ensuring the reuse and recycling of recyclables without any potential forms of health risks. Furthermore, a policy for waste treatment infrastructure at the community level should also be promulgated. This can be in the form of on-site waste treatment facilities at hospitals and various communities, including locally made autoclaving machines, incinerators, and controlled landfills for biodegradable materials. The decentralization policy of solid waste management would ensure appropriate and timely treatment of different kinds of wastes close to where they are generated and avoid unintended hijacking or spillover of hazardous wastes in the environment. Other treatment techniques that can be employed for the increasing generation of hazardous wastes based on the technical expertise, accessibility, and resources availability and affordability include pyrolysis, thermal or heat-inactivation treatment, microwave, and radio wave treatment, dry heat treatment, gas sterilization, ultraviolet germicide irradiation, and use of chemicals as disinfectants $[69,70]$.

Thirdly, due to the capital-intensive nature of waste management and the inadequate waste management structure in developing and less developed countries, the sharing of the cost of waste management should be extended to the consumers in the form of a pay-as-you-throw policy. This policy is needed for robust and sustainable financing of logistic supports that are required for efficient waste management services. The pay-as-you-throw policy is already in place in some of the developed countries, and success recorded in the efficient and sustainable management of solid wastes through the implementation of the policy has been noted [26]. This policy, if well implemented, would address the issue of infrequent collection and transportation of generated wastes from households to the appropriate treatment facilities as more personnel and infrastructure would be deployed for such tasks due to the availability of funds.

Fourthly, open dumping and unregulated landfills should be banned, while the construction of landfills and their accessibility should be institutionalized in such a way that adequate consideration would be placed on the environmental and health risks of the residences around such facility. Since the practice of open dumping and involvement of unregulated landfills are encouraged due to the inadequate access to waste collection and waste disposal facilities [9], there is a need to provide adequate infrastructure for waste collection, transportation, and disposal that could ensure safe and efficient management of the generated wastes. Most importantly, the sensitization of the citizens on the dangers of open dumping and unregulated construction of landfills within the neighborhood on the environment and their health should be strengthened, especially during the COVID-19 era and future pandemics.

Lastly, a new waste management policy should be enforced or integrated into the existing policy to create an alternative waste management approach in a coordinated flow from disposal point to the treatment unit, especially for hazardous wastes generated from different households and healthcare facilities, which is to be managed at the community level. A unique color code bin can be proposed for storing such hazardous waste. This policy approach would ensure that proper training on waste management and provision of essential protection kits are provided for the community-based actors involving in the waste management and handling of hazardous wastes. The unfortunate situation of scavengers or waste pickers without proper protective wears handling the hazardous waste materials [17], making them vulnerable to infections like COVID-19 while looking for daily livelihoods [15], would be adequately prevented as the hazardous waste materials would have been decontaminated and separated from other wastes. Other general policy response measures that could be implemented include:

1. Non-knowledgeable people about healthcare waste management should be banned to be at the forefront of solid waste management, especially as long as the current pandemic persists.

2. Medical waste must be collected separately and disposed of after proper disinfection to reduce the possible consequential health and environmental effects that might be a herculean task to handle if the government disregards the effect of this contagion on the environment. 
3. In circumstances where there is limited skilled manpower, training programs should be organized for people who will be employed to handle these infectious wastes.

4. Sensitization via TV, radio, posters, seminars, conferences, and other social media platforms should be done and well coordinated regularly to educate and bring awareness to everyone about the need to ensure safe and reliable municipal solid waste management.

5. Access to landfills by countless informal workers picking up and selling recyclables from the waste stream to meet their daily needs should be restricted because these informal workers are particularly vulnerable to infect themselves, which can be easily transmitted to others.

6. Although waste recycling is an efficient way of conserving natural resources and preventing pollution, as a result of the emergence of COVID-19, the widespread practice of single-use products should be intensified and recycling of wastes should be suspended to reduce the risk of spreading the virus in the recycling centers.

7. Since waste is linked with the soil and indirectly to the water bodies, wastewater treatment plants should strengthen their disinfection procedures to inhibit the spread of the new coronavirus via wastewater reuse.

8. Incineration or deep burial of anatomical waste such as human tissue should be adopted only where there is no access to a biomedical waste treatment facility in rural or remote areas.

9. Face masks produced from polymers are drastically increasing, thereby intensifying waste management issues which can result in plastic or microplastic pollution. Biodegradable polymer materials including high molecular weight polyethylene (HMPE), engineered fibers, natural polymers, aramids, sponge nitrile, polyurethane, etc. should be used for the manufacturing of PPEs. Besides this, the carbon and water footprint of manufacturing materials should be lesser as compared to other available chemically synthesized materials.

\section{Conclusions}

The significant danger of snowballing transmission of COVID-19 via inappropriate management of expended PPEs cannot be overemphasized. The enormous increase in the number of cases coupled with the pre-existing inefficient solid waste management system in the developing nations calls for viable approaches to curb the proliferation of COVID-19. Moreover, the increasing reported cases of infected people with COVID-19 in developing countries could further the existing stringent rule on the mandatory use of facemasks and the possible extension of lockdowns across these countries, thereby leading to compounding problems of solid waste management of expended PPEs.
Therefore, there is a need for revising the existing waste management policies in developing nations in tandem with what is obtainable in the twenty-first century to sustainably and efficiently address the environmental and health challenges emanating from increasing waste generation and unexpected scenarios like the COVID-19 pandemic and other future ones. More so, the sustainable approaches proposed in this study are indispensable to address the solid waste generated from handling the COVID-19 pandemic.

Funding The authors extend their appreciation to the Scientific Research Deanship at King Khalid University and the Ministry of Education in Saudi Arabia for funding this research work through the project number IFP-KKU-2020/3.

\section{Declarations}

Conflicts of interest The authors declared no potential conflicts of interest with respect to the research, authorship, and/or publication of this article.

\section{References}

1. WHO (2020) Statement on the second meeting of the International Health Regulations (2005) Emergency Committee regarding the outbreak of novel coronavirus (2019-nCoV). https://www.who.int/ news-room/detail/30-01-2020-statement-on-the-second-meetingof-the-international-health-regulations-(2005)-emergency-commi ttee-regarding-the-outbreak-of-novel-coronavirus-(2019-ncov). Accessed on 31 May 2020

2. WHO (2020) Coronavirus Disease 2019. In: Coronavirus Dis. Situat. Rep. - 206. https://www.who.int/docs/default-source/ coronaviruse/situation-reports/20200813-covid-19-sitrep-206. pdf?sfvrsn=bf38f66b_6. Accessed on 14 Aug 2020

3. Ajibade FO, Adelodun B, Lasisi KH et al (2021) Environmental pollution and their socioeconomic impacts. In: Kumar A, Singh VK, Singh P, Mishra VK (eds) Microbe mediated remediation of environmental contaminants. Elsevier, pp 321-354

4. Adelodun B, Ajibade FO, Ibrahim RG et al (2020) Snowballing transmission of COVID-19 (SARS-CoV-2) through wastewater: any sustainable preventive measures to curtail the scourge in lowincome countries? Sci Total Environ. https://doi.org/10.1016/j. scitotenv.2020.140680

5. Urban RC, Nakada LYK (2021) COVID-19 pandemic: Solid waste and environmental impacts in Brazil. Sci Total Environ. https:// doi.org/10.1016/j.scitotenv.2020.142471

6. Adelodun B, Ajibade FO, Ighalo JO et al (2021) Assessment of socioeconomic inequality based on virus-contaminated water usage in developing countries: a review. Environ Res. https://doi. org/10.1016/j.envres.2020.110309

7. Anand U, Adelodun B, Pivato A et al (2021) A review of the presence of SARS-CoV-2 RNA in wastewater and airborne particulates and its use for virus spreading surveillance. Environ Res. https://doi.org/10.1016/j.envres.2021.110929

8. Adelodun B, Tiamiyu AO, Ajibade FO et al (2021) Presence, detection, and persistence of SARS-CoV-2 in wastewater and the sustainable remedial measures. In: Dehghani MH, Karri RR, Roy $\mathrm{S}$ (eds) Environmental and health management of novel coronavirus disease (COVID-19). Elsevier, pp 91-114 
9. Oyedotun TDT, Kasim OF, Famewo A et al (2020) Municipal waste management in the era of COVID-19: Perceptions, practices, and potentials for research in developing countries. Res Glob. https://doi.org/10.1016/j.resglo.2020.100033

10. Zand AD, Heir AV (2020) Environmental impacts of new Coronavirus outbreak in Iran with an emphasis on waste management sector. J Mater Cycles Waste Manag 23:240-247. https://doi. org/10.1007/s10163-020-01123-1

11. Swarajya (2020) India Becomes World's 2nd Largest PPE Kit Producer In Just Two Months; Develops World's First Reusable PPE Suit. https://swarajyamag.com/insta/india-becomesworlds-2nd-largest-ppe-kit-producer-in-just-two-months-devel ops-world-first-reusable-ppe-suit. Accessed on 21 Jun 2020

12. Kalina M, Tilley E (2020) "This is our next problem": Cleaning up from the COVID-19 response. Waste Manag 108:202-205. https://doi.org/10.1016/j.wasman.2020.05.006

13. Kareem KY, Adelodun B, Tiamiyu AO et al (2021) Effects of COVID-19: An Environmental Point of View. In: Hussain CM, Shukla SK (eds) Detection and Analysis of SARS Coronavirus. Wiley, KGaA, Weinheim, Germany, pp 219-242

14. The Economic Times (2020) Fine, jail term for not wearing mask when outside home in Delhi . https://economictimes.india times.com/news/politics-and-nation/fine-jail-term-for-not-weari ng-mask-when-outside-home-in-delhi/articleshow/75065520. cms. Accessed on 28 May 2020

15. Nzediegwu C, Chang SX (2020) Improper solid waste management increases potential for COVID-19 spread in developing countries. Resour Conserv Recycl. https://doi.org/10.1016/j. resconrec.2020.104947

16. Worldometer (2020) Population by Country. https://www. worldometers.info/world-population/population-by-country/. Accessed on 10 Jan 2021

17. Haque MS, Uddin S, Sayem SM, Mohib KM (2021) Coronavirus disease 2019 (COVID-19) induced waste scenario: a short overview. J Environ Chem Eng. https://doi.org/10.1016/j.jece. 2020.104660

18. Ajibade FO, Adelodun B, Ajibade TF et al (2021) The threatening effects of open dumping on soil at waste disposal sites of Akure City, Nigeria. Int J Environ Waste Manag 27:127-146. https://doi.org/10.1504/IJEWM.2021.10030610

19. Adelodun B, Ajibade FO, Tiamiyu AO et al (2021) Monitoring the presence and persistence of SARS-CoV-2 in water-foodenvironmental compartments: State of the knowledge and research needs. Environ Res. https://doi.org/10.1016/j.envres. 2021.111373

20. Ro C (2020) Why litter is surging as lockdowns ease . In: BBC. https://www.bbc.com/worklife/article/20200610-why-are-parksfull-of-litter-as-lockdown-eases. Accessed on 14 Mar 2021

21. Ramteke S, Sahu BL (2020) Novel coronavirus disease 2019 (COVID-19) pandemic: considerations for the biomedical waste sector in India. Case Stud Chem Environ Eng. https://doi.org/10. 1016/j.cscee.2020.100029

22. Noufal M, Maalla Z, Adipah S (2021) Households' participation in solid waste management system of Homs city, Syria. GeoJournal 86:1441-1463. https://doi.org/10.1007/s10708-020-10139-x

23. Isine I (2020) SCARY: Amateur Video Shows Man Disposing PPE Outside Abuja Cemetery after Abba Kyari's Burial . In: Next Ed. https://www.nextedition.com.ng/scary-amateur-video-showsman-disposing-ppe-outside-abuja-cemetery-after-abba-kyarisburial. Accessed on 14 Mar 2021

24. Sinthumule N, Mkumbuzi S (2019) Participation in CommunityBased Solid Waste Management in Nkulumane Suburb, Bulawayo. Zimbabwe Res 8:30. https://doi.org/10.3390/resources8 010030

25. Serge Kubanza N (2021) The role of community participation in solid waste management in Sub-Saharan Africa: a study of
Orlando East, Johannesburg, South Africa. South African Geogr J 103:223-236. https://doi.org/10.1080/03736245.2020.17277 72

26. Adelodun B, Kim SH, Choi K (2021) Assessment of food waste generation and composition among Korean households using novel sampling and statistical approaches. Waste Manag 122:71-80. https://doi.org/10.1016/j.wasman.2021.01.003

27. Vassanadumrongdee S, Kittipongvises S (2018) Factors influencing source separation intention and willingness to pay for improving waste management in Bangkok, Thailand. Sustain Environ Res 28:90-99. https://doi.org/10.1016/j.serj.2017.11. 003

28. Debrah JK, Vidal DG, Dinis MAP (2021) Raising awareness on solid waste management through formal education for Sustainability: a developing countries evidence review. Recycling 6:6. https://doi.org/10.3390/recycling6010006

29. Aleluia J, Ferrão P (2017) Assessing the costs of municipal solid waste treatment technologies in developing Asian countries. Waste Manag 69:592-608. https://doi.org/10.1016/j.wasman. 2017.08.047

30. Song Q, Wang Z, Li J (2016) Residents' attitudes and willingness to pay for solid waste management in Macau. Procedia Environ Sci 31:635-643. https://doi.org/10.1016/j.proenv.2016.02.116

31. Boateng KS, Agyei-Baffour P, Boateng D et al (2019) Household willingness-to-pay for improved solid waste management services in four major metropolitan cities in Ghana. J Environ Public Health. https://doi.org/10.1155/2019/5468381

32. Ferronato N, Torretta V (2019) Waste mismanagement in developing countries: a review of global issues. Int J Environ Res Public Health. https://doi.org/10.3390/ijerph16061060

33. Sarkodie SA, Owusu PA (2020) Impact of COVID-19 pandemic on waste management. Environ Dev Sustain. https://doi.org/10. 1007/s10668-020-00956-y

34. Sharma HB, Vanapalli KR, Cheela VS et al (2020) Challenges, opportunities, and innovations for effective solid waste management during and post COVID-19 pandemic. Resour Conserv Recycl. https://doi.org/10.1016/j.resconrec.2020.105052

35. van Doremalen N, Bushmaker T, Morris DH et al (2020) Aerosol and surface stability of SARS-CoV-2 as compared with SARSCoV-1. N Engl J Med 382:1-4. https://doi.org/10.1056/NEJMc 2004973

36. Mavrokefalidis D (2020) Coronavirus face masks "could have a devastating effect on the environment" - Energy Live News. https://www.energylivenews.com/2020/03/17/coronavirus-facemasks-could-have-a-devastating-effect-on-the-environment/. Accessed on 28 May 2020

37. Saber DA, Howlett B, Waterman T, de Tantillo L (2018) Solid waste and disposal processes for isolated patients with infectious disease. Online J Issues Nurs. https://doi.org/10.3912/OJIN.Vol23 No02PPT33

38. Ali M, Wang W, Chaudhry N, Geng Y (2017) Hospital waste management in developing countries: a mini review. Waste Manag Res J a Sustain Circ Econ 35:581-592. https://doi.org/10.1177/ $0734242 X 17691344$

39. Taş A, Özer AY (2020) Waste disposal and management in radiopharmaceuticals. Fabad J Pharm Sci 45:91-103

40. Mohiuddin A (2018) Medical waste: a nobody's responsibility after disposal. Int J Environ Sci Nat Resour. https://doi.org/10. 19080/JJESNR.2018.15.555908

41. Banerjee P, Hazra A, Ghosh P, Ganguly A (2019) Solid Waste Management in India: A Brief Review. In: Ghosh SK (ed) Waste Management and Resource Efficiency. Springer, Singapore, pp $1027-1049$

42. Chand S, Shastry CS, Hiremath S et al (2020) Water, sanitation, hygiene and biomedical waste disposal in the healthcare system: A review. Biomedicine 40:2020 
43. Mol MPG, Caldas S (2020) Can the human coronavirus epidemic also spread through solid waste? Waste Manag Res 38:485-486. https://doi.org/10.1177/0734242X20918312

44. Oluwatuyi OE, Ajibade FO, Ajibade TF et al (2020) Total concentration, contamination status and distribution of elements in a Nigerian State dumpsites soil. Environ Sustain Indic. https://doi. org/10.1016/j.indic.2020.100021

45. David VE, John Y, Hussain S (2020) Rethinking sustainability: a review of Liberia's municipal solid waste management systems, status, and challenges. J Mater Cycles Waste Manag 22:1299_ 1317. https://doi.org/10.1007/s10163-020-01046-x

46. Awodele O, Adewoye AA, Oparah AC (2016) Assessment of medical waste management in seven hospitals in Lagos, Nigeria. BMC Public Health 16:1-11. https://doi.org/10.1186/ s12889-016-2916-1

47. Vasistha P, Ganguly R, Gupta AK (2018) Biomedical waste generation and management in public sector hospital in Shimla City. In: Singh V, Yadav SYR (eds) Environmental Pollution, 1st edn. Springer, Himachal Pradesh, India, pp 225-232

48. Adeoye AO, Akande EA, Lateef A (2018) Impacts of hospital waste management on the health and environment of Ogbomoso area. Hosp Palliat Med Int J, Oyo. https://doi.org/10.15406/hpmij. 2018.02.00130

49. Ahmad R, Liu G, Santagata R et al (2019) LCA of hospital solid waste treatment alternatives in a developing country: The Case of District Swat, Pakistan. Sustainability 11:3501. https://doi.org/10. 3390/su11133501

50. Ali M, Wang W, Chaudhry N (2016) Application of life cycle assessment for hospital solid waste management: a case study. J Air Waste Manage Assoc 66:1012-1018. https://doi.org/10.1080/ 10962247.2016.1196263

51. Khadem Ghasemi M, Mohd Yusuff R (2016) Advantages and disadvantages of healthcare waste treatment and disposal alternatives: Malaysian scenario. Polish J Environ Stud. https://doi. org/10.15244/pjoes/59322

52. Mukhtar S, Khan H, Kiani Z et al (2018) Hospital waste management: execution in Pakistan and environmental concerns-a review. Environ Contam Rev. https://doi.org/10.26480/ecr.01. 2018.18.23

53. Alam I, Alam G, Ayub S, Siddiqui AA (2019) Assessment of biomedical waste management in different hospitals in Aligarh City. Advances in waste management. Springer, Singapore, pp 501-510

54. Dehghani M, Vafadar M (2017) Qualitative and Quantitative Survey and Suggested Management Strategy of Hospital Solid Waste at Hormozgan Province Iran. Ambient Sci. https://doi.org/ 10.21276/ambi.2017.04.1.ra04

55. Goyal KC, Goyal SKN, Goyal R (2017) Analysis of bio-medical waste of a private hospital in patiala city, punjab, india. Octa $\mathbf{J}$ Environ Res 5:1-5

56. Habib A, Nahar SK, Tazrin T (2018) Hospital waste management in Rajshahi City. Asian J Innov Res Sci Eng Technol 1:14-20

57. Jaiswal S, Tiwari BR, Joshi KR et al (2017) Medical waste disposal practices in hospital based different clinical laboratories of Pokhara Valley. Int J Perceptions Public Heal 1:143-147

58. Oli AN, Ekejindu CC, Adje DU et al (2016) Healthcare waste management in selected government and private hospitals in Southeast Nigeria. Asian Pac J Trop Biomed 6:84-89. https:// doi.org/10.1016/j.apjtb.2015.09.019
59. Rajan R, Robin DT, Vandanarani M (2019) Biomedical waste management in Ayurveda hospitals - current practices and future prospectives. J Ayurveda Integr Med 10:214-221. https://doi.org/ 10.1016/j.jaim.2017.07.011

60. Al-Khatib IA, Eleyan D, Garfield J (2016) A system dynamics approach for hospital waste management in a city in a developing country: the case of Nablus. Palestine Environ Monit Assess. https://doi.org/10.1007/s10661-016-5487-9

61. Ansari M, Ehrampoush MH, Farzadkia M, Ahmadi E (2019) Dynamic assessment of economic and environmental performance index and generation, composition, environmental and human health risks of hospital solid waste in developing countries: a state of the art of review. Environ Int. https://doi.org/10.1016/j.envint. 2019.105073

62. de Araujo RCFS, Machado MER, Rodrigues RP, Fialho AAR (2018) A study about the disposal of solid waste of healthin a public hospital institution in Sant'ana do Livramento town. Rev Adm da UFSM 11:421-434. https://doi.org/10.5902/1983465929 477

63. Farzadkia M, Akbari H, Gholami H, Darabi A (2018) Management of hospital waste: a case study in Tehran. Iran Heal Scope. https://doi.org/10.5812/jhealthscope.61412

64. Maulana M, Kusnanto H, Suwarni A (2016) Solid Waste Management in Hospital Jogja. Int J Public Heal Sci 5:247. https://doi.org/ 10.11591/.v5i3.4792

65. Namvar Z, Asgharnia H, Fallah H, Amouei A (2016) Survey of hospital solid waste management in North of Iran. Int J Hosp Res 5:64-68. https://doi.org/10.15171/ijhr.2016.12

66. Afon AO, Afolabi AS, Agbabiaka HI, Akinbinu AA (2017) Determinants of hospital solid waste composition of Obafemi Awolowo University Teaching Hospital Complex (OAUTHC) Ile-Ife. Nigeria Cogent Environ Sci. https://doi.org/10.1080/23311843.2017. 1300863

67. Klemeš JJ, Van FY, Tan RR, Jiang P (2020) Minimising the present and future plastic waste, energy and environmental footprints related to COVID-19. Renew Sustain Energy Rev. https://doi.org/ 10.1016/j.rser.2020.109883

68. Ryan PG, Maclean K, Weideman EA (2020) The impact of the COVID-19 lockdown on urban street Litter in South Africa. Environ Process 7:1303-1312. https://doi.org/10.1007/ s40710-020-00472-1

69. Ilyas S, Srivastava RR, Kim H (2020) Disinfection technology and strategies for COVID-19 hospital and bio-medical waste management. Sci Total Environ. https://doi.org/10.1016/j.scitotenv.2020. 141652

70. Tiamiyu AO, Adelodun B, Bakare HO et al (2021) Role of Nanotechnology in Coronavirus Detection. In: Hussain CM, Shukla SK (eds) Detection and Analysis of SARS Coronavirus. Wiley, pp 87-103

Publisher's Note Springer Nature remains neutral with regard to jurisdictional claims in published maps and institutional affiliations. 